PREFACE

\title{
Writing East Germany into Cold War History
}

On February 9, I990, U.S. president George H. W. Bush sat down to pen a personal letter to West German federal chancellor Helmut Kohl. He wanted Kohl to know that he wholeheartedly supported the chancellor's accelerated drive toward German unification. The situation in the German Democratic Republic (GDR) had been deteriorating. For many East Germans, change in the wake of the fall of the Berlin Wall on November 9, 1989, could not come fast enough. Thousands of East Germans went west, putting pressure on Kohl for fast-track unification. The West German leader was about to confront Soviet Communist Party secretary general Mikhail Gorbachev, who, by all accounts, held the key to Germany's unity. Bush assured his German counterpart of "the complete readiness of the United States to see the fulfillment of the deepest national aspirations of the German people. If events are moving faster than expected, it just means that our common goal for all these years of German unity will be realized even sooner than we had hoped." In characterizing his support of Kohl, Bush was on the mark. Sooner than other European leaders, the American president had developed a "comfort level" with the idea of German unification: "I'd love to see Germany reunited," Bush told the Washington Times on May I6, 1989. It reflected his belief, as Robert Gates, the then-deputy national security adviser, later recalled, that "the Germans had changed, and he was prepared to gamble a great deal on that faith." ${ }^{3}$ The president's conviction that West Germany had become a stable democracy and a reliable ally positioned him and his administration to embrace the idea of a united Germany sooner than others, including the Germans themselves. His advisers, too, believed that "there 
is no German of any age who does not dream of it in his soul." ${ }^{4}$ But it was more than sympathy for the Germans that motivated the Bush administration in its support for German unity: it made the alliance with West Germany the centerpiece of its strategy to preserve U.S. preeminence on the European continent. The Bush administration's support for German unification, Robert Hutchings, a National Security Council (NSC) official at the time, recalled, was "genuine, consistent with our principles and based on careful consideration of our interests." 5

Yet the grand narrative of Americans and Germans standing side by side "for all these years" in the pursuit of Germany unity, so evocatively suggested by Bush's letter to Kohl, reduces the complex story of U.S. policy toward the German question since the end of World War II. This study looks at that story's early years, from Allied occupation to the early I950s, when both West Germany and East Germany became members of the politico-military pacts facing off against each other in Europe. It does so through the prism of American attitudes and policy toward the Soviet-controlled part of Germany. It was these Germans, caught by the post-I945 geopolitical fallout of the war that Nazi Germany had launched in I939, who most dearly paid the price of the country's division. ${ }^{6}$ Histories of the American-German relationships in the postwar era have left these Germans largely out of the narrative. This book seeks to write the East Germans-leadership and populace-back into history, certainly as objects of American policy, at times even as historical agents of their own.

Was there an American policy toward East Germany? Two major intellectualpolitical projects for a long time relegated the answer to this question to a footnote. One was the perception, prevailing for most of the Cold War, of the USSR's dominating role in the Soviet occupation zone and later the German Democratic Republic. In this view, generally speaking, the GDR as part of the Soviet-led eastern bloc lacked historical agency. American policy was thus directed at the Soviets in Germany; based on the "supreme authority" the four occupation powers had assumed in Germany in June I945, the United States held the USSR responsible for events in the Soviet zone and GDR.. If there was a distinctive U.S. approach to East Germany in this perspective, it was one of diplomatic non-recognition of the Communist German regime after I949, a policy that sought to deprive that regime of any legitimacy and aligned with the West German "Hallstein Doctrine," which punished recognition of the GDR by other countries. During the Cold War and beyond, many historians unconsciously echoed the dominant political view in the West by denying the GDR historical agency. Not until I989 did a book by a political scientist address the topic more fully, although it focused on 
the period after the resumption of relations between the United States and the GDR in $1974 .^{7}$

The more important reason for the lack of inquiries into U.S. policy toward East Germany was the primacy of the American relationship with "its" Germany. To this day, the alliance the United States forged with the Federal Republic of Germany (FRG) "represents one of the most successful endeavors in the history of U.S. diplomacy." Turning the western part of Germany from a wartime adversary to an economically and politically pluralistic, vibrant, and peaceful ally was and is considered critical to the post-World War II reconstruction and stabilization of Western Europe and the global liberal-capitalist system, vital to America's prevailing in the Cold War, and central to assuring U.S. predominance on the European continent once the Soviet empire had crumbled. ${ }^{8}$

Emblematic of the importance of West Germany to the United States, President Bush in May 1989 called for both countries to become "partners in leadership." With a great deal of merit, generations of historians in the United States and Germany and beyond have written libraries full of books exploring every aspect of America's relationship with the Federal Republic. Whether supportive of the relationship in which both countries had invested so much, or critical of the mistakes, failures, and moral or political compromises that had been involved, however, these bodies of work were by and large united in their neglect of East Germany as a serious factor in forging the relationship. ${ }^{?}$

This book is made possible by two recent historiographic shifts, both facilitated in part by access to declassified documents. First, a greater appreciation for the fact that U.S. foreign policy in the early phase of the Cold War was far more assertive in nature than the defensive posture implied by the notion of "containment." Since the late I940s, reactive, defensive notions of "containing" this new Soviet threat mixed in the political discourse in Washington with more activist and offensively conceived notions of "liberation" and of "rollback" of Soviet power. Benefiting from increased declassification of formerly secret documents in the I980s, Melvyn Leffler's Preponderance of Power (1992) finally provided persuasive documentation that U.S. objectives had been more far-reaching than previously acknowledged. American planners, Leffler argued, wanted to redraw Russia's borders to their preI939 status, destroy the Cominform, "retract" influence of the Soviet Union, and eventually cause the Soviet system to weaken and decay. Given time and strength, containment could evolve into a "rollback" of Soviet power. On the basis of declassified top-level U.S. planning papers, Gregory Mitrovich and Peter Grose pushed this notion even further: Rollback did not await successful containment. The Truman 
administration embarked on a strategy to "compel" the Soviet Union to abandon its international ambitions in sync with its containment policy. ${ }^{10}$

Notions of "rollback" and "liberation" struck a deeper chord because, as Bernd Stöver has demonstrated, they related to traditional American political paradigms of liberty and Manifest Destiny, linked to the religiously infused ideology of American exceptionalism and America's moral superiority that had motivated U.S. interventionism from the nineteenth century until the world wars of the twentieth. Faced with yet another "totalitarian challenge" to its very concept of modernity in the wake of the German Reich's defeat, the United States saw itself as assisting the "natural" or "divine" trends of world history and defending its own security at the same time as it sought to expand the domains of freedom abroad. The United States, therefore, could not limit itself to the "long-term, patient but firm and vigilant containment of Russian expansive tendencies" alone, as U.S. diplomat George F. Kennan had_now famously_demanded in his I 947 Foreign Affairs article "The Sources of Soviet Conduct.”

Led in fact by Kennan himself, American officials had set out in 1947-48 to destabilize the Soviet regime and its East European "satellites" through a concerted "psychological warfare" effort-termed "counteroffensive" - that sought to further exploit "vulnerabilities" of the Soviet system, particularly its pervasive distrust and suspicion, and "rollback" Soviet domination from Central Europe. East Germany constituted an important target in this "counteroffensive" strategy, especially after the North Korean invasion of South Korea led to a dramatic rise in Cold War tensions globally. This study benefited from the unprecedented openness and declassification of U.S. government records through the Freedom of Information Act (FOIA) _ including records on covert operations and psychological warfare. More recently, new scholarship based on exclusive access to the archives of West Germany's foreign intelligence service, led by German historians Jost Dülfer, Klaus-Dietmar Henke, Wofgang Krieger, and Rolf-Dieter Müller, has enriched the Western perspective. ${ }^{11}$

Second, with the end of the Cold War, the implosion of the Communist regimes in east-central Europe, the disintegration of the Soviet Union, and the ensuing opening of archives of the former Communist world, historians have also sought to internationalize the history of the Cold War. Gaining access to the innermost chambers of secrets of the formerly ruling Communist parties from Moscow to Berlin has allowed historians to recast the Cold War in ways that were unthinkable beforehand: the narrative could now be reconstructed from an international perspective, on a multi-archival basis, overcoming the one-sided, largely Western-centered perspectives that had dominated scholarship in East and West. ${ }^{12}$ The sudden end 
of the Cold War confrontation posed the challenge to historians to write its history knowing the outcome, yet it also allowed them to escape the ideological and political parameters that it seemed to have set while it was ongoing.

The German battleground of the Cold War has always formed an important sub-narrative. Reflecting the larger debate on the origins of the Cold War, during the Cold War (and beyond) historians fought and refought the battle over who was to blame for the division of Germany. During the height of the Cold War, most Western accounts laid the blame squarely at Stalin's doorstep. Much of the late Cold War-era scholarship had firmly grounded American policy toward postwar Germany in the containment paradigm. To be sure, the notion of a "double" or "dual" containment developed by Wolfram Hanrieder and Thomas Alan Schwartz added subtlety to the notion that Washington was solely preoccupied with countering Soviet expansionism into Europe. ${ }^{13}$ With the U.S. and British sources well exploited by the late I980s, the study of American policy in Germany during the first postwar decade took a cultural and transnational turn in the I990s. Reflecting similar trends in other fields, major works of the I990s emphasize the significance of ideological or cultural agendas and discourse as well as the importance of nonstate, nongovernmental actors in the international arena of the postwar period. ${ }^{14}$

Though over time historians came to question the Cold War consensus, only Carolyn Eisenberg finally turned the historiographic tables, with her 1996 work Drawing the Line: The American Decision to Divide Germany, 1944-1949. The United States_along with Britain and France, not the Soviet Union-Eisenberg argued in what has become the standard account of the subject, was the architect of Germany's partition. Lacking access to archival sources in Germany and Russia, Eisenberg's brilliant account, however, tended to underestimate Soviet responsibility. In other ways, it did not go far enough in analyzing U.S. responsibility. This study is meant to complement Eisenberg's account in the light of new Russian and German documentation. It also builds on Marc Trachtenberg's pathbreaking work, especially his A Constructed Peace (1999). ${ }^{15}$

What these new and important contributions, including works by Hermann Josef Rupieper and Frank Schumacher, had in common — and indeed what united them with landmark earlier studies such as John Lewis Gaddis's The Long Peace: Inquiries into the History of the Cold War (1987) and Melvyn Leffler's Preponderance of Power (1992) — was the fact that they paid little attention to East Germany, as either an object or an actor in the story that unfolded. Still mirroring the American political vantage point, much of the scholarship focused on West Germany and, in line with the longtime denial of diplomatic recognition, ignored the eastern part of the country and treated it as a negligible appendage. Other studies subsumed the 
GDR as a Soviet "satellite," as part of the political east-central Europe, famously written off to Soviet domination by American "non-policy." ${ }^{16}$ Even in works on German-American relations, including classics by John H. Backer, Frank Ninkovich, Wolfgang Krieger, and Thomas Schwartz, developments in eastern Germany found scant mention. ${ }^{17}$ Only recently have a number of new publications - among them work by Anjana Buckow, Schanett Riller, and Burton C. Gaida-focused greater attention on certain aspects of the American approach to the "other" Germany. ${ }^{18}$

The scholarship deficit on the GDR diminished when the doors of the archives of the Socialist Unity Party of Germany (Sozialistische Einheitspartei Deutschlands, or SED), and the government that it ran were flung open in the wake of the fall of the Berlin Wall. ${ }^{19}$ To be sure, the GDR had been a subject of serious study in West Germany before reunification, particularly by the Mannheimer Arbeitskreis "Geschichte und Politik der DDR," led by Hermann Weber, as well as other experts, such as Karl Wilhelm Fricke, Gisela Helwig, Peter Christian Ludz, Ilse Spittmann, and Carola Stern, but it remained handicapped by the dearth of sources. ${ }^{20}$ Much like the broader debate about the Cold War in the United States, the study of the GDR reflected the political debate and exigencies in the Federal Republic about Deutschlandpolitik, from the early totalitarian critique of the I950s to the "systemic" understanding of the GDR as a modernizing society in the détente years. Only access to the archives in eastern Germany (and Russia) after I989-90 allowed historians in East and West Germany to begin a critical reassessment of the political and social history, the "historicization" of the "second German state."21

Since the early I990s, the history of East Germany (and the relations between both German states) has witnessed an explosion of new research. In this process, a new generation of historians born and/or educated in the GDR_-in particular IlkoSascha Kowalczuk, Michael Lemke, Andreas Malycha, Armin Mitter, and Stefan Wolle, liberated from the prerequisites of Marxist-Leninist ideological frameworkhave played a leading role in reassessing GDR history. ${ }^{22}$ International historians have joined this proliferation of research on postwar eastern Germany, with landmark studies by Timothy Garton Ash, Catherine Epstein, Hope Harrison, Konrad Jarausch, and Norman Naimark. ${ }^{23}$ Between Containment and Rollback builds on this rich archival corpus of documents and analytical literature to show how American policy affected events in East Germany; access to these resources has allowed this study to give historical agency to the East German leaders and "masses" as they faced the West.

While the events of June I953 and the Soviet occupation period drew much public and scholarly attention, research on international history based on the former East German records preoccupied itself largely with German-German relations, with 
an emphasis on the period after $1960 .{ }^{24}$ Studies of GDR foreign policy generally suffered from two circumstances: First, despite the setting up of a foreign ministry in the GDR in 1949, international affairs remained a tightly guarded prerogative of the Soviet occupation power, particularly in the immediate postwar period, but to a great degree into the 1950 s as well. Thus the German record, exemplified by the important but often cryptic Pieck diary notes, has been fragmentary at best. ${ }^{25}$ Second, until the early 200os, Russian records for the early postwar period in Germany remained inaccessible in the Presidential Archive and the Russian Foreign Ministry Archive in Moscow. ${ }^{26}$ Thanks to the patient efforts of Jochen Laufer, Elke Scherstjanoi, Jan Foitzik, and others at the Zentrum für zeithistorische Forschung in Potsdam and the Institute for Contemporary Research in Munich/Berlin, Russian records on occupied Germany have begun to be published in cooperation with the Russian Foreign Ministry Archive. Norman Naimark, Bernd Bonwetsch Gennadij Bordjugov and Gerhard Wettig published additional important Russian documentation for the period under consideration in this study. Though far from complete, these records, supplemented with Russian records relating to Germany from other collections and archives, have informed this study to the extent that they allow, for the first time in a fairly systematic fashion, insights into Soviet (and German) intentions and actions vis-à-vis the United States and its allies. ${ }^{27}$ 
This page intentionally left blank 